Received: Jan 12, 2018; Accepted: May 17, 2018; Published: Jun 19, 2018; Paper Id.: IJMPERDJUN2018116

\title{
INTRODUCTION
}

\section{Data of the Problem}

The Hyderabad Transformed Division of manufactures transformers used by industrial plants, schools, public institutions, commercial construction projects and hospitals. The plant engineer generally makes the purchase decision so the objective is to maximize the number of plant engineers reached, given budgetary and other constraints. The company has Rs. 25,000/- to spend on industrial advertising and data are available on markets reached by various media. The required information is given in the following table: 
Table 1

\begin{tabular}{|c|l|l|c|c|}
\hline $\begin{array}{c}\text { S. } \\
\text { No }\end{array}$ & Variables & \multicolumn{1}{|c|}{ Magazine } & $\begin{array}{c}\text { Plant Engineers } \\
\text { Reached/ Cost per } \\
\text { Production }\end{array}$ & $\begin{array}{c}\text { Plant Engineers } \\
\text { Reached per Rupees. }\end{array}$ \\
\hline 1 & $\mathrm{X}_{1}$ & Construction Engineer & $0 / 475$ & 0 \\
\hline 2 & $\mathrm{X}_{2}$ & Electrical Engineer & $12,000 / 792$ & 15.15 \\
\hline 3 & $\mathrm{X}_{3}$ & Electrical Worked & $24,000 / 730$ & 32.87 \\
\hline 4 & $\mathrm{X}_{4}$ & Power & $44,000 / 890$ & 49.44 \\
\hline 5 & $\mathrm{X}_{5}$ & Plant Engineering & $52,000 / 918$ & 56.65 \\
\hline 6 & $\mathrm{X}_{6}$ & Electrical Weet & $8,000 / 456$ & 17.54 \\
\hline 7 & $\mathrm{X}_{7}$ & Electrified Industry & $44,000 / 756$ & 58.20 \\
\hline 8 & $\mathrm{X}_{8}$ & Public Power & $0 / 700$ & 0 \\
\hline 9 & $\mathrm{X}_{9}$ & Electric Light and Power & $16,000 / 680$ & 23.53 \\
\hline 10 & $\mathrm{X}_{10}$ & Transmission and Distribution & $23,000 / 575$ & 40.00 \\
\hline
\end{tabular}

\section{Goal Programming Model}

The general GP model can be stated as follows:

$\underset{\text { Minimize }}{Z}=\sum_{i=1}^{m} w_{i}\left(d_{i}^{+}+d_{i}^{-}\right)$

Subject to the constraints

$$
\sum_{i=1}^{m} a_{i j} x_{i}+d_{i} \quad d_{i}^{\prime}=b_{i}, i=1,2,3, \ldots m \text { and } x_{i}, d_{i}^{-}, d_{i}^{+} \geq 0 \text { for all } i \text { and } j \text {. }
$$

Where $m$ goals are expressed by $m$ - components, columns $b_{i}, x_{i}$ represents a decision variable, ${ }^{a_{l}}$ represents the coefficient for the $i^{i h}$ constraint, ${ }^{\boldsymbol{w}_{i}}$ represents the weights attached to each goal and $d_{i}^{-}, d_{i}^{+}$are deviational variables representing the amount of under and over achievement of the $i^{i h}$ goal respectively. If goals are classified into the $k$ ranks, the pre-emptive priority factors should be assigned to the deviational variables $d_{i}^{-}$and $d_{i}^{+}$according to their order of importance. The $p$ 's are not given actual values, they are simply a confinement way of indicating that one goal is more important that another. The priority factors have the relationship $p_{j}>>>>n p_{j+1}(\mathrm{j}=1,2,3, . . \mathrm{k})$ where $n$ is very large. This implies that multiplied by $\mathrm{n}$ however large it may be, cannot have $n p_{j+1}$ greater than $p_{j}$. They are lower priority goal will never be achieved at the exposure of a high priority goal.

The deviational variables at the same priority level may be given different weights in the objective function so that deviational variables within the same priority have different cardinal weights. Since both under and over achievement of goal cannot be achieved simultaneously, either one or both of these deviational variables will be equal to zero. The decision maker must analyze each one of the $m$-goals in the model in terms of whether over achievement is acceptable $d_{i}^{+}$can be removed from the objective function. On the other hand, if under achievement is acceptable $d_{i}^{-}$can be removed from the objective function. If exact achievement of the goals is desired both $d_{i}^{-}$and $d_{i}^{+}$must be included in the objective function and ranked according to their presumed priority factors from the most important to the least important. In this way the lower order goals are considered only after the higher goals are achieved as desired. Mathematically the GP model can 
be described as follows:

$\underset{\text { Minimize }}{z}=\sum_{i=1}^{n} p_{i} d_{r}^{-}$

Subject to the following constraints.

\section{Budget Constraints}

$x_{1}+x_{2}+x_{3}+x_{4}+x_{5}+x_{6}+x_{7}+x_{8}+x_{9}+x_{10}+d_{i}^{-}-d_{i}^{+}=R s .25,000 /-$

In addition, constraints must be fixed to prevent more rupees being invested in any one monthly magazine that is necessary to buy 10 in sections. Therefore, these constraints as follows:

$$
\begin{aligned}
& x_{1}+d_{1}^{-}-d_{1}^{+}=5700 \\
& x_{2}+d_{2}^{-}-d_{2}^{+}=9504 \\
& x_{3}+d_{3}^{-}-d_{3}^{+}=8760 \\
& x_{4}+d_{4}^{-}-d_{4}^{+}=4912 \\
& x_{5}+d_{5}^{-}-d_{5}^{+}=11016 \\
& x_{6}+d_{6}^{-}-d_{6}^{+}=5472 \\
& x_{7}+d_{7}^{-}-d_{7}^{+}=9072 \\
& x_{8}+d_{8}^{-}-d_{8}^{+}=3300 \\
& x_{9}+d_{9}^{-}-d_{9}^{+}=8160 \\
& x_{10}+d_{10}{ }^{-}-d_{10}^{+}=6900
\end{aligned}
$$

\section{RESULTS AND DISCUSSIONS}

The solution is obtained by using $\mathrm{QSB}^{+}$computer software and an optimal solution indicated that an investment of Rs. 4,912/- in power $\left(\mathrm{X}_{4}\right)$, Rs. 11,016/- in plant engineering $\left(\mathrm{X}_{5}\right)$, and Rs. 9,072/- in electric field industry $\left(\mathrm{X}_{7}\right)$ would maximize the number of plant engineers reached for Rs. 25,000/-.

It is apparent that same media are better than other for reaching desired objectives and we need the same form of effectiveness rating. In other words, the media buyers must be certain that we have chosen the media which must watch the audience as specified by the objective.

\section{REFERENCES}

1. Agostini J M, How to estimate induplicate audiences. Journal of advertising research, 13, (1961), 11-14.

2. Caballero R, Francisco R M, Victoria U, Carlos R, Interactive meta Goal Programming, European Journal of Operational Research, (2006), 175, 135-154.

3. Chen Tang Y, Ter Chang C, "Multi criteria decision-making based on goal programming and fuzzy analytic hierarchy process: An application to capital budgeting problem" Knowledge-based Systems, 26, (2012), 288-293.

4. Churchman C et.al, Introduction to Operations research. John Wileg and Sons, (1967), New York. 
5. Day Ralph L, Linear Programming in Media Selection.. Journal of advertising research, (1962), 40-44

6. Dorn WS (1963): Non Linear Programming of survey. Management Sciences 9, 171-208.

7. Harish Babu GA and Uday Kumar KN, “A Goal Programming Model for Public Accounting Firms”-International Journal of Applied Engineering Research, 10(14), (2015), 34097 - 34102.

8. Harish Babu G A and Uday Kumar K N, “Aggregate Manpower Planning - A Goal Programming Approach”- Pure and Applied Mathematics Journal, 4(6), (2015), 233 - 236.

9. Naai-Jung, S. (2016). Experiencing an Informal Dining Route Through the 3D Scanned Data of Urban Fabric. Browser Download This Paper.

10. Harish Babu GA and Jayashree D N, "Optimal allocation of in-patent in acute care Hospitals” International Journal of Recent Scientific Research, 7(4), (2016), 10272 - 10275.

11. Tien, Y. S., Cheng, H. C., Hu, J., Hsu, C. L., \& Chen, S. S. (2016). Decision Making with Multi-Criteria Assessment: How Firms to Select Appropriate Collaboration Partner?.

12. Harish Babu GA and Jayashree D, "Optimum allocation of resources in University Management through Goal Programming" Global Journal of Pure and Applied Mathematics, 12(4), (2016), 2777-2784.

13. Seram, N., \& Dhramakeerthi, C. (2016). Wearable Technology Products: Awareness in Sri Lankan Market.

14. Safari S, A, Sardari A, Sabzian H, "Designing a Mathematical Model for Allocating Budget to University Research and Educational Goals: A Case Studey in Shahed University". Iranian Journal of Management Studies, 5(2), (2012), 89-113

15. Zamfirescu L, Bela Zamfirescu C, "Goal Programming as a Decision Model for Performance-Based Budgeting". Procedia Computer Science, First International Conference on Information Technology and Quantitative Management, 17, (2013), 427433. 